\title{
Efeitos da Globalização e da Sociedade em Rede Via Internet na Formação de Identidades Contemporâneas
}

\author{
Effects of the globalization and of the network society on the constitutions of the
} contemporary identities via internet

Resumo: A sociedade em rede, através da mídia e da internet, é o resultado de transformações econômicas, tecnológicas, sociais e culturais que abrangem todo o planeta, fenômenos esses chamados genericamente de globalização. Este artigo investiga tais mudanças no âmbito da Psicologia, em particular no que se refere à formação de identidades contemporâneas. Inicialmente, são discutidas as principais correntes teóricas da Comunicação e a internet como mídia interativa, para então abordar aspectos psicológicos relativos à globalização nos caminhos da internet e como estes podem influenciar novas maneiras de construir relações sociais e atividades que criam novas visões de mundo.

Palavras-Chave: Globalização, mídia, comunicação de massa, internet, identidade, relações sociais, sociedade em rede.

Abstract:The network society created by the mass media and the internet is the outcome of economical, technological, social and cultural changes that affect the whole planet, which are known generically as globalization. This article investigates such changes in the context of Psychology, particularly their role in the formation of contemporary identities. Main communication theories and the internet as an interactive media are discussed, as well as the psychological aspects in relation to the globalization by way of the internet and how these affect social activities and relationships that shape new worldviews.

Key Words: Globalization, mass media, internet, identity, social relationships, network society.

Marcelo Deiro Prates da Silveira
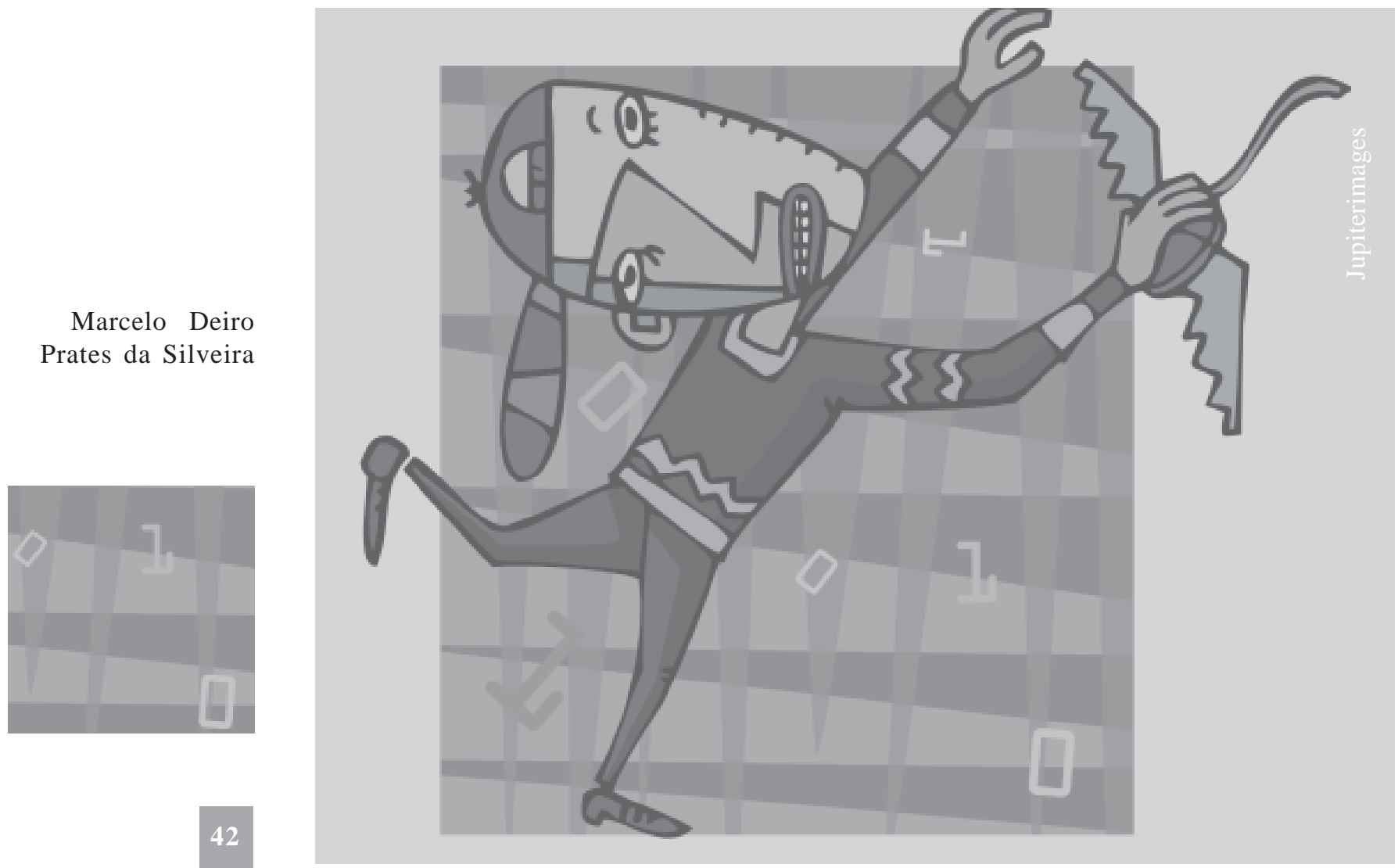
Até alguns anos atrás, os teóricos da comunicação definiam como mídia de massa apenas a imprensa, o cinema, o rádio e a televisão. No início da década de 90, os sistemas eletrônicos interativos baseados em computação e telefonia eram definidos como mídias emergentes (DeFleur \& Ball-Rokeach, 1993), mas, atualmente, a internet já é tratada como uma nova mídia de massa (Hohlfeldt, Martino \& França, 2001; Moraes, 2003). A rede de computadores que forma a internet saiu das redes de pesquisas de universidades e outras instituições para se tornar um sistema de comunicação que abrange expressivas parcelas da população em grande parte do mundo, o que a transformou em parte da cultura de massa (Castells, 2000 e 2003; Leitão e Nicolaci-da-Costa, 2000 e 2003).

Se os processos comunicativos, no interior da cultura de massa, são objeto da Comunicação (Hohlfeldt, Martino \& França, 2001), os seus efeitos e a sua interação com a cultura e sociedade podem ser objeto de estudo da Psicologia, Sociologia, Antropologia e de outras áreas do conhecimento. Nosso objetivo é investigar a influência da globalização e da mídia, particularmente da internet e dos meios digitais, na constituição de identidades contemporâneas. Procuramos mostrar que a internet não se encaixa no paradigma tradicional das teorias da comunicação, que pressupõe passividade e fragilidade dos receptores da comunicação, levando a novas possibilidades na relação do sujeito com essa mídia, em particular na maneira pela qual a internet se torna um meio para comportamentos que contribuem para formar identidades.

Nicolaci-da-Costa (2002c) afirma que as múltiplas transformações introduzidas pelas tecnologias digitais podem causar mudanças subjetivas comparáveis àquelas causadas pela Revolução Industrial ao longo dos séculos XIX e XX. Ao avaliar a importância de considerar as novas tecnologias como fatores de subjetivação, Leitão e Nicolacida-Costa (2003) argumentam sobre a necessidade de os psicólogos estarem atentos e informados sobre as transformações introduzidas pela revolução digital, concluindo que:

“... um conhecimento mais aprofundado das transformações radicais em curso no mundo atual pode ajudar os psicólogos a rever suas antigas certezas a respeito do homem e a aventurar novos olhares sobre os também novos fenômenos humanos".

Acreditamos que, do ponto de vista da Psicologia, o aspecto mais importante seja o de avaliar o papel da internet nos aspectos diários e corriqueiros que têm influência na maneira como nos comunicamos e nos relacionamos, como trabalhamos e como entendemos o mundo.

\section{A Diversidade das Teorias da Comunicação de Massa}

Ainda que o nosso referencial seja a Psicologia, torna-se necessário apresentar aspectos básicos dos principais referenciais teóricos da Comunicação. Estes se caracterizam pela diversidade de correntes e concepções, existindo uma dificuldade em reunir e classificar tendências e escolas (Hohlfeldt et al., 2001). Esses autores descreveram as principais referências no estudo da mídia e o que se observa no seu trabalho é que, tal como na Psicologia, também na Comunicação existem vários referenciais teóricos, tanto complementares como conflitantes. Umberto Eco (1973, p. 29), no seu estilo irônico, afirma que elaborar uma teoria dos meios de massa "equivaleria a conceber uma teoria do Dia de São Nunca”. Assim, como não é possível reunir todas as correntes numa única classificação abrangente, procuramos definir, de maneira sucinta, algumas das mais difundidas correntes teóricas que serão úteis para o tema deste artigo.

\section{O Funcionalismo Norte-Americano}

O foco da teoria funcionalista está na interação social, supondo, como funções da comunicação de massa, informar, interpretar e socializar, estudando tanto a função como a disfunção, ou seja, os aspectos positivos e negativos dos meios de comunicação (Bosi, 1981). A transmissão de informações, por exemplo, tem o duplo aspecto de colocar em pauta temas importantes para a sociedade, mas também o de gerar um excesso de informações que pode deixar o espectador ou o leitor confuso. Para Martino (2001), os objetos de estudo privilegiados pelo funcionalismo norteamericano são a persuasão, o controle social, as gratificações e os processos de produção da notícia. O funcionalismo norte-americano, em geral, deixa de lado a análise dos instrumentos tecnológicos e a sua dimensão histórica, aspectos que possuem destaque em outras correntes teóricas (Martino, 2001).

\section{A Teoria da Indústria Cultural da Escola de Frankfurt}

A escola de Frankfurt é influenciada pelos conceitos marxistas de conflito, alienação e história, tendo uma abordagem mais voltada para os aspectos socio-políticos e econômicos dos processos de comunicação (Martino, 2001). Nessa abordagem, o conceito fundamental é o de
“... um conhecimento mais aprofundado das transformações radicais em curso no mundo atual pode ajudar os psicólogos a rever suas antigas certezas a respeito do homem e a aventurar novos olhares sobre os também novos fenômenos humanos".

Leitão e Nicolaci-daCosta 
indústria cultural. A música, o cinema e as artes, nos meios de massa, são vistos como quaisquer outros produtos do capitalismo, cuja comercialização visa apenas o lucro e a expansão de mercados. As manifestações culturais são vistas como produtos fabricados em série exatamente como numa linha de montagem, de forma semelhante a quaisquer outros produtos industriais (Hohlfeldt, 2001). Para os teóricos dessa corrente, a cultura de massa é resultado de uma colonização política e econômica que se faz acompanhar da colonização cultural. Seus opositores afirmam que é uma abordagem excessivamente ideológica. Para Umberto Eco (1973, p. 11-12), indústria cultural é um "conceito-fetiche" que "tem a particularidade de bloquear o discurso, enrijecendo o colóquio num ato de reação emotiva”.

\section{O Meio é a Mensagem na Teoria Cibernética}

O aforismo "o meio é a mensagem”, de Marshall McLuhan, resume a idéia central dessa teoria: o fato de que os meios eletrônicos, como rádio, cinema e televisão, permitem a expressão da comunicação através de vários sentidos (visão, audição) que haviam sido perdidos quando as tradições orais cederam espaço aos meios escritos depois do advento da imprensa (Bosi, 1981). Essa retomada da comunicação supostamente mais próxima à expressão humana natural, em contraste com a linearidade, fragmentação e abstração necessárias à escrita, levariam a vivências, através da mídia eletrônica, capazes de retribalizar comunidades distantes, criando uma "aldeia global” (Bosi, 1981).

\section{Apocalípticos e Integrados: Diferenças e Fatores em Comum nas Teorias da Comunicação de Massa}

Umberto Eco (1976) usa uma terminologia sarcástica para classificar as diferentes teorias da comunicação: ele as divide entre as apocalípticas e as integradas. As integradas, tais como os adeptos do funcionalismo norte-americano, representam o paradigma da ordem, com uma tendência pragmática e otimista sobre o papel e as possibilidades da mídia. Por outro lado, as apocalípticas são as que adotam o discurso do conflito e da crítica, como os representantes da escola de Frankfurt, com um discurso mais pessimista, descrente sobre uma eventual evolução positiva no papel da mídia (Eco, 1976). perspectiva funcionalista para verificar a maneira mais eficiente de transmitir uma mensagem, mas também se pode adotar um ponto de vista mais crítico, como o dos adeptos da escola de Frankfurt, e analisar como essa mensagem é criada para manipular a opinião pública de forma a maximizar o lucro e o controle social. Ainda uma terceira opção seria analisar a tecnologia dos meios de comunicação como extensões físicas do homem, como na teoria cibernética. De uma forma ou de outra, todas as teorias possuem, em comum, o fato de que os meios de comunicação influenciam comportamentos e atitudes e são capazes de influenciar ou determinar identidades culturais e sociais (Ferreira, 2001). Em outras palavras, elas destacam a fragilidade do indivíduo frente aos meios de comunicação. Em todas as teorias, existe uma assimetria, uma diferença abissal entre o poder da mídia e a vulnerabilidade do indivíduo, visto como impotente e incapaz de resistir aos apelos da mídia (Ferreira, 2001).

\section{Internet e Meios Digitais como Novas Mídias Interativas}

Torna-se necessário investigar como e se a internet se encaixa no perfil da mídia que é objeto de estudo daquelas teorias da comunicação. Procuramos mostrar que a internet não se encaixa no paradigma que pressupõe uma passividade e fragilidade dos receptores da comunicação.

A internet é mídia com características de interatividade radicalmente diferentes dos demais meios de comunicação (Castells, 2003a; Nicolacida-Costa, 2002c e 2003; Terêncio e Soares, 2003). O paradigma da comunicação de massa pressupõe um comunicador (ou emissor) gerando e transmitindo uma mensagem, através de um código, para um receptor (ou destinatário) com fins de informação, entretenimento, controle, persuasão, etc. (Bosi, 1981; Eco, 1973; Pignatari, 1996). Ainda que o comunicador não pressuponha um receptor passivo, este tem relativamente poucas escolhas no momento da comunicação, pois os conteúdos da mídia são pré-determinados e selecionados (Abramo, 2003; Hohlfeldt et al., 2001; Silverstone, 2002). O modelo de comunicação da internet pressupõe uma interatividade, em que se exige maior atividade do "receptor", muitas vezes no próprio momento em que a transmissão está acontecendo. Em alguns casos, o "receptor" tornase, simultaneamente, comunicador ou, pelo menos, tem o poder de influenciar o comunicador no próprio instante da geração e transmissão de sua mensagem. Além disso, o "receptor" pode selecionar a abrangência e a profundidade com que os temas tratados (Castells, 2003a).

A comunicação de massa tradicional pressupõe uma difusão um-para-muitos unidirecional dos 
órgãos de comunicação para a sociedade, enquanto a convergência dos meios digitais através da internet permite também a comunicação umpara-um, muitos-para-um ou muitos-para-muitos através de email, grupos de discussão em websites e sistemas de chat (Levy, 2003; Castells, 2003a). Para Castells (2003b), um influente sociólogo que estuda o impacto da internet na sociedade e economia mundiais, o aspecto inédito é que, pela primeira vez na História, existe uma capacidade maciça de comunicação não intermediada pelas empresas e meios de comunicação de massa. Em nossa opinião, isso derruba, em parte, a tese da vitimização do indivíduo frente aos meios de comunicação, colocando ainda mais em evidência um aspecto levantado por Eco (1973) já na década de 70 :

"Na realidade, o uso indiscriminado de um conceito-fetiche como esse de 'indústria cultural', implica, no fundo, a incapacidade mesma de aceitar esses eventos históricos [novas tecnologias de comunicação], e - com eles - a perspectiva de uma humanidade que saiba operar sobre a história.”

\section{A Convergência digital na Globalização, Economia e Organizações}

Assistimos a uma sempre crescente revolução das tecnologias digitais, que abrange a convergência dos meios de telecomunicação com sistemas de computação. A internet constitui-se no meio mais amplamente conhecido dessa convergência digital, com profundo impacto em novas formas de relacionamentos pessoais e sociais, novas possibilidades de pesquisa e aprendizagem, novos tipos de organizações e formas de trabalho (Belar, Nelson e Wasik, 2003; Levy, 2003; Castells, 2000, 2003a e 2003b; Nicolaci-da-Costa, 2002a, 2002b, 2002c e 2003; Pinto de Almeida e Rodrigues, 2003; Silverstone, 2002; Terêncio e Soares, 2003). Além disso, a rede mundial de computadores (internet) também se constitui num novo instrumento para a globalização econômica e cultural, com conseqüências positivas e negativas em diversas áreas (Moraes, 2003). Para Castells (2000 e 2003b), a sociedade em rede é o resultado desse conjunto de transformações que abrange, direta ou indiretamente, todas as camadas sociais em todas as regiões do mundo.

Como a convergência digital resultou numa mudança de paradigma nas comunicações, de uma mídia unidirecional para uma multimídia interativa, diversificam-se e multiplicam-se os fluxos de informações financeiras, comerciais e culturais em todo o planeta (Moraes, 2003). Em termos mais específicos, a convergência digital mistura software com entretenimento digital (jogos, filmes, música), serviços de notícia, lazer, publicidade e marketing através de websites com as informações viajando por redes de satélites, fibras óticas e cabos de alta velocidade (Castells, 2003a; Moraes, 2003).

A globalização também leva a fusões e reestruturações de empresas, mudanças de capital e de unidades de produção para outros países onde a mão-de-obra é mais barata, em geral mantendo o controle administrativo, a distribuição e o marketing nos seus países de origem. Tal situação impulsiona mudanças no modelo organizacional que somente se tornam possíveis através de tecnologias de comunicação e softwares integrados através da internet (Moraes, 2003, p. 193). A conseqüência imediata dessas reestruturações é tanto o aumento de produtividade e a expansão de algumas economias periféricas como também demissões e aviltação do emprego com redução de salários, terceirização, perdas de direitos trabalhistas e previdenciários (Arnett, 2002; Castells, 2003b; Moraes, 2003).

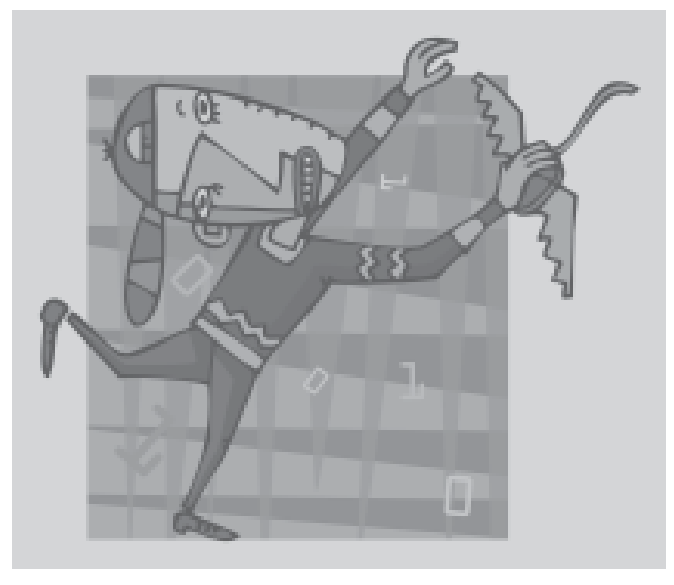

“...indústria cultural é um "conceito-fetiche" que "tem a particularidade de bloquear o discurso, enrijecendo o colóquio num ato de reação emotiva”.

Umberto Eco

\section{O Poder Midiático e a Internet}

O poder da mídia levanta questões como a diminuição do papel do Estado, o enfraquecimento da sociedade civil e dos laços comunitários, com a conseqüente necessidade de regulamentação do setor através dos órgãos governamentais e/ou da sociedade civil (Moraes, 2003). Também nessa área, a internet possui pontos comuns e divergentes das outras mídias sob vários aspectos. Tal como entre as empresas de mídia convencionais, existe uma concentração dos principais serviços da internet nas mãos de poucas empresas, no Brasil e no mundo. As diferenças abrangem vários aspectos: a regulamentação da internet depende muito de entidades internacionais, mas essa regulamentação torna-se mais limitada devido às características 
tecnológicas desse meio, de difícil controle, como atestam o tráfego de vírus, as invasões de sistemas pelos hackers e a publicação de pornografia infantil e de mensagens de organizações criminosas pela rede. Nas mídias convencionais, a regulamentação é dirigida às empresas detentoras dos meios, mas a comunicação na internet pode acontecer diretamente entre os usuários. Por outro lado, esse aspecto possibilita a organização de movimentos sociais como ativismo ecológico, movimentos antiglobalização e de valorização de minorias culturais e sociais (Castells, 2003b).

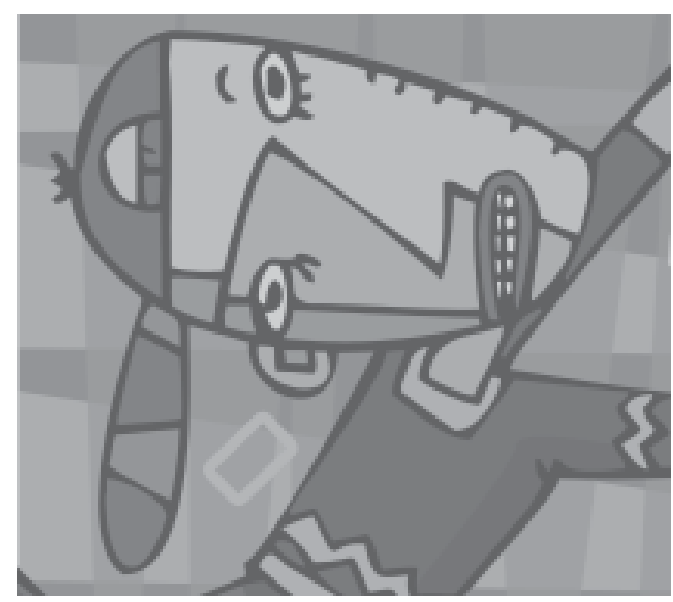

\section{Algumas Conseqüências Psicológicas da Globalização Econômica e Cultural}

A globalização envolve uma grande variedade de fenômenos econômicos, sociais e culturais. O foco que transparece na mídia geralmente é aquele abordado na Economia, enquanto estudiosos da Comunicação tendem a focalizar a questão em torno do poder da mídia e do enfraquecimento da sociedade civil (Moraes, 2003). No que tange à Psicologia, não somente esses aspectos devem ser levados em consideração mas também outras conseqüências psicológicas, sociais e culturais (Eidelwein e Maraschin, 2003; Leitão e Nicolacida-Costa, 2003; Nicolaci-da-Costa, 2002a, 2002b, 2002c e 2003; Terêncio e Soares, 2003). Cabe, então, indagar: quais as contribuições da Psicologia para compreender os processos envolvidos na globalização (Arnett, 2002)?

Arnett (2002), um psicólogo que avaliou a psicologia da globalização a partir de relatos de pesquisas em várias partes do mundo, tais como países árabes, africanos, latino-americanos, no sul da Ásia e no Extremo Oriente, afirma que os psicólogos raramente estudam ou avaliam aspectos ligados diretamente à globalização e que muitas pesquisas nessa área ainda devem ser feitas. Ele evidencia quatro principais conseqüências psicológicas derivadas da globalização: a existência de identidades biculturais, confusões de identidade, possibilidade de escolhas individuais entre diferentes culturas e a existência de um período de vida adulta com características de adolescência continuada, salientando que estas são observadas majoritariamente nas classes médias urbanas de quase todos os países.

Sob o aspecto de identidades biculturais, Arnett (2002) situa o fato de que parte da identidade, especialmente de adolescentes, é enraizada na cultura local e parte é influenciada pela cultura global. Por cultura global, entende-se aquela liderada por países ocidentais desenvolvidos que induzem valores orientados por individualismo, consumismo e liberdade de mercado, em consonância com o que preconizam os adeptos da teoria da indústria cultural, mas também a democracia, direitos humanos e liberdades individuais. Ainda segundo Arnett (2002), uma certa confusão de identidades está crescendo entre jovens de culturas não ocidentais devido à globalização. Adolescentes e adultos jovens não mais se sentem confortáveis ou participantes nem de sua cultura local, nem da cultura global.

\section{Sociedade em Rede: a Formação de Identidades e Socialização Via Internet}

Como vimos, a internet e o computador são mais do que meios de comunicação e instrumentos de trabalho, são também meios de interação e organização essenciais para a sociedade contemporânea em rede (Castells, 2000, 2003a e 2003b; Levy, 1998 e 2003; Terêncio e Soares, 2003). Computadores conectados à internet estão presentes em boa parte dos lares de classe média e alta, em escolas particulares e públicas e em grande número de empresas, de pequeno a grande porte. Embora o acesso doméstico à internet no Brasil esteja limitado, em grande parte, às classes mais favorecidas, a sua influência não é restrita a essas classes. A circulação das informações na rede e o respectivo impacto sobre o trabalho e empregabilidade, sobre as organizações e a economia em geral fazem com que a influência da internet abranja, praticamente, toda a sociedade (Castells, 2000, 2003a e 2003b). Além disso, o acesso à internet também começa a se tornar possível a partir de escolas públicas e de empresas que estimulam funcionários de diferentes níveis a usar a internet como ferramenta de trabalho e aprendizagem online.

Teóricos e profissionais da Comunicação referemse à internet tanto como apenas mídia instrumental 
para a difusão da economia de mercado globalizante e da "Cultura McWorld” (Barber, 2003) mas também como ambiente virtual capaz de gerar cooperação e participação democráticas inigualáveis na história da humanidade (Castells, 2000; Levy, 2003). Diversas variações existem entre esses dois extremos, que lembram a divisão entre os apocalípticos e os integrados de Umberto Eco (1976). Uma teoria que nos parece apropriada para avaliar a internet na sociedade em rede é a derivada das idéias de McLuhan. A sua máxima "o meio é a mensagem" pode ser transposta e expandida para situar a internet não apenas como tecnologia ou mídia, mas como extensões físicas do homem que lhe permitem não apenas comunicar-se de formas diferentes, mas principalmente relacionar-se e trabalhar de formas que não existiam antes do advento da rede.

Procuramos, a seguir, fazer uma avaliação no que exatamente a convergência de meios digitais através da internet difere das outras mídias em relação ao trabalho, relações pessoais e culturais e, em particular, em relação àqueles aspectos que Arnett (2002) focalizou como conseqüências psicológicas da globalização, ou seja, as influências multiculturais nas identidades em diferentes partes do mundo.

\section{A Socialização Via Internet}

As pessoas, na vida adulta intermediária e adiante, ou seja, a partir dos 40 anos (Bee, 1997), tendem a usar a internet para atividades similares às existentes antes do advento dessa tecnologia: enviar e receber email em substituição às ligações telefônicas e ao correio tradicional e usar a web para obter notícias, pesquisar informações, fazer compras online e divulgar atividades profissionais. Por outro lado, crianças, adolescentes e adultos mais jovens adotam novos usos para a internet. Eles a usam para a formação de novas relações de amizade e amorosas e para se integrarem a "tribos" eletrônicas que funcionam como as turmas ou "panelinhas" da vida real. Essas relações tanto podem manter-se apenas online como ser um trampolim para relacionamentos "reais", face a face (Clay, 2000; Gonçalves, 2000; Kraut et al., 2003; Nicolaci-da-Costa, 2002a e 2002b). Diálogos mantidos em salas de chat, por exemplo, são usados para encontrar amizades, parceiros sexuais e amorosos fora do ambiente virtual da internet. Os psicólogos que investigam oportunidades e desafios para a pesquisa psicológica online avaliam que, da mesma forma que a internet facilita a pesquisa de informações e compras online, também torna os encontros românticos ou puramente sexuais mais fáceis e mais rápidos de acontecer (Kraut et al., 2003, p. 33).
Ao investigar usuários experientes da internet através de entrevistas face a face, Nicolaci-da-Costa (2002a e 2002b) sugere a necessidade de interpretações positivas dessas novas formas de comunicação em oposição ao discurso da mídia e de alguns psicólogos que rotulam como vício ou como alienante o uso intensivo da rede. Terêncio e Soares (2003) avaliam a internet como uma ferramenta útil para o desenvolvimento da identidade profissional e afirmam que, no campo de orientação profissional, os psicólogos não podem ficar alheios a essa nova ferramenta. Eidelwein e Maraschin (2003) investigaram a operação de um grupo de discussão por email e têm a opinião que essa forma de comunicação pode levar a formas concretas de atuação em grupo fora do espaço digital. Pinto de Almeida e Rodrigues (2003) afirmam que, a cibercultura um dos retratos da contemporaneidade, e teorizam sobre a possibilidade de se estabelecerem novas modalidades de terapia online num futuro próximo, especialmente quando as tecnologias que permitem troca de som e de imagem estiverem mais desenvolvidas e popularizadas.

Os exemplos acima sugerem que os psicólogos devem estar atentos às possibilidades, atuais e futuras, apresentadas pela comunicação em rede, sob pena de verem limitadas as suas capacidades de atuar sobre a História.

\section{A Influência da Internet na Subjetivação e no Desejo}

Vimos que a análise da comunicação de massa pode ser abordada através de diferentes pontos de vista, mas a abordagem adotada aqui para avaliar efeitos subjetivos da internet será aquela indicada por Silverstone (2002) para investigar a comunicação de massa: avaliar os seus efeitos cotidianos, pois é aí que "a mídia opera de maneira mais significativa” (Silverstone, 2002, p. 20). Isso quer dizer que o que deve ser analisado não é a maneira como os grandes eventos jornalísticos (guerras, catástrofes, crises políticas e econômicas) são apresentados, mas, sim, a maneira mais sutil, nem sempre evidente, de como a mídia estabelece referências que influenciam comportamentos e atitudes no dia-a-dia das pessoas. Silverstone (2002) faz um paralelo dessa abordagem com a análise de conteúdos manifestos e latentes usados por Freud para a interpretação dos sonhos. O ponto de partida da análise de Silverstone (2002) é que a mídia é onipresente e diária na sociedade moderna. Nós dependemos da mídia não apenas para lazer, entretenimento e informações mas também para obtermos uma sensação de conforto e segurança capazes de criar um sentido na nossa existência cotidiana. Como afirma Silverstone

\section{A globalização envolve uma grande variedade de fenômenos econômicos, sociais e culturais. O foco que transparece na mídia geralmente é aquele abordado na Economia, enquanto estudiosos da Comunicação tendem a focalizar a questão em torno do poder da mídia e do enfraquecimento da sociedade civil}

Moraes, 2003 
(2002, p. 24), ligar a TV ou abrir o jornal nos liga a outros que estão fazendo a mesma coisa. A busca de informações e de entretenimento equivale ao conteúdo manifesto, enquanto a obtenção de conforto e segurança são partes do conteúdo latente, inconsciente, na relação com a mídia e com os outros. Nas palavras de Souza (2003), ao transmitir notícias e imagens, a televisão está "simulando a participação do sujeito na vida pública”.

De forma análoga ao papel das mídias convencionais analisadas por Silverstone (2002), usar a internet para trocar emails, colocar opiniões em grupos de discussão na web e conversar em salas de chat produzem uma sensação de proximidade, de fazer parte da mesma "turma" eletrônica. A interatividade e a imediaticidade dos diálogos online, sem precedentes nas outras mídias, acentuam ainda mais aquela sensação de familiaridade a que Silverstone se refere, mesmo que o contato direto esteja ausente. A ausência de contato físico, entretanto, não implica uma ausência de contato emocional e cognitivo, ainda que mediados pelo computador. Os comportamentos do emissor são traduzidos em texto, imagens e sons que viajam nas linhas telefônicas, cabos e satélites para serem reproduzidos no computador do receptor. Os toques que seriam dirigidos ao corpo do outro são transformados em entusiasmada digitação no teclado. Os olhares de admiração, dúvida, interrogação e excitação são dirigidos ao texto e às imagens na tela do computador. Emoções, fantasias, desejos são criados e instigados, levando a amizades, paixões, amores, que podem resultar em sexo virtual ou real. Por sexo virtual, entendese duas pessoas mantendo um diálogo através de computador, geralmente através de chat, usando conteúdo explicitamente sexual que visa a excitação mútua, possivelmente acompanhada de masturbação (Clay, 2000).

Os relacionamentos sociais através da internet provavelmente serão temas importantes também para a Psicologia, pois a emergência das comunidades virtuais constitui um dos maiores acontecimentos sociológicos dos últimos cinco anos, de acordo com Levy (2003), um dos mais influentes pesquisadores sobre o impacto da internet na sociedade. Os relacionamentos online e suas conseqüências na e fora da rede ainda são um terreno pouco pesquisado na Psicologia. Os primeiros relatos de pesquisas nessa área procuram responder perguntas como: a internet está aumentando as conexões interpessoais ou levando a maior isolamento? O sexo virtual é patológico ou saudável? (Clay, 2000) Existe uma adição à internet? O uso excessivo da internet pode resultar em problemas na família, no casamento ou no trabalho? (Nicolaci-da-Costa, 2002a e 2002b) O envolvimento em temas e conversas sexuais online leva ao sexo offline (fora da rede)? (DeAngelis, 2000) Como se protege a intimidade online? (Nicolacida-Costa, 2003) Qual o papel da internet na transformação da identidade pessoal e profissional? (Terêncio e Soares, 2003) Quais as possibilidades e limites da psicoterapia mediada pelo computador? (Pinto de Almeida e Rodrigues, 2003).

Em resumo, a internet, como mídia, é um importante meio para atividades que ajudam a formar identidades e subjetividades. Do ponto de vista da Psicologia, o aspecto mais importante é avaliar o seu papel naquilo que Silverstone (2002) chama de "textura da experiência", isto é, o conjunto dos aspectos diários, corriqueiros, muitas vezes banais, que têm influência na maneira como nos comunicamos e nos relacionamos, como trabalhamos e como entendemos o mundo.

\section{Influências da Internet nas Culturas Locais e na Relação com a Cultura Global}

Investigar o papel da internet na textura da experiência também é avaliar como ela influencia a transmissão de valores e altera as relações entre as culturas locais e a cultura global. Provavelmente, o efeito mais aparente da internet em relação às culturas locais é o de exacerbar os efeitos das mídias convencionais há bastante tempo denunciados pelas teorias críticas derivadas da escola de Frankfurt: favorecer o avanço sem fronteiras da indústria cultural, unificando valores, crenças, estilos de vida e determinando padrões de consumo, com o conseqüente enfraquecimento de identidades culturais e de laços comunitários tradicionais.

Entretanto, os valores levados pelas mídias convencionais a todos os cantos do mundo e que constituem o que se refere genericamente como cultura global não se limitam ao individualismo, materialismo, hedonismo e consumismo. Também fazem parte dessa cultura global a democracia, direitos humanos, igualdade racial e de gênero, liberdades individuais, como liberdade de orientação sexual, liberdade religiosa, liberdade de escolher parceiros amorosos e carreiras profissionais (Morin, 2002). Tais valores, longe de serem universais, são centrados na liderança de países industrializados do Ocidente e, muitas vezes, entram em conflito com as culturas locais (Arnett, 2002). Estudos de diferentes partes do mundo, como África, Ásia, América Latina e Oriente Médio, analisados por Arnett (2002), indicam que pessoas jovens de todo o planeta adotam, parcialmente, 
uma identidade ligada a essa cultura global, desenvolvendo um senso de pertencimento a essa cultura, não necessariamente conflitante com a sua cultura original, podendo ser complementar e integrada às culturas locais. Até recentemente, a televisão exerceu o papel mais importante no desenvolvimento dessas identidades culturais globais, mas Arnett (2002) afirma que, provavelmente, a internet está tornando-se mais importante do que a televisão para os mais jovens porque ela permite a comunicação direta com pessoas de qualquer parte do planeta através de email e chat e porque fornece acesso direto a informações de todo o mundo.

\section{Marginalização, Confusão de Identidades e Exclusão Digital}

A influência da globalização e da mídia não se limita à integração "bem resolvida" de mais de uma cultura em identidades híbridas ou multiculturais, que, em geral, limitam-se aos jovens de classe média (Arnett, 2002). Quando os jovens são expostos aos valores da cultura global, podem perder o interesse em manter sua cultura original, mas também rejeitarem ou não se integrarem à nova cultura porque esta vai contra os seus valores ou por falta de oportunidades, emprego, baixa renda, etc. (Arnett, 2002). O resultado é o que Arnett chama de confusão de identidades, com a conseqüente marginalização e tendência a maiores taxas de depressão, suicídio e abuso de drogas. Esse processo de aculturação seguido de marginalização é bastante conhecido entre nós e já foi estudado em profundidade no Brasil, em especial com relação às populações descendentes de negros africanos e indígenas (Ribeiro, 1995). Em nosso país, além daquelas conseqüências mencionadas por Arnett (2002), temos o aumento da violência urbana e do envolvimento de populações carentes com atividades ilícitas, tais como contrabando e tráfico de drogas (Noto e Formigoni, 2002; Zaluar, 2002).

Se esse processo de marginalização não é desconhecido para nós, brasileiros, um novo fator de risco está em emergência, com possibilidade de aumentar as desigualdades sociais: a exclusão e a divisão digital, a separação entre uma parcela da sociedade com acesso à internet e às tecnologias mais recentes e outra que vê, adicionadas às suas já existentes desvantagens, a falta de acesso aos serviços, informações e aprendizagens disponíveis apenas na rede, tendo como resultado a diminuição de sua inserção na economia (Castells, 2003; Foxhall, 2000).

Outra conseqüência da confusão de identidades, segundo Arnett (2002), é a possibilidade de escolhas individuais entre diferentes culturas. Essas escolhas são aquelas que pessoas com interesses e visões em comum fazem ao unir-se a determinados grupos para adquirir um senso de identidade que não é mais possível obter nem na cultura local, nem na cultura global. Nessa categoria, Arnett (2002) cita como exemplos os grupos religiosos fundamentalistas, os movimentos sociais antiglobalização e grupos que reagem de maneira relativamente desorganizada, como os metaleiros (heavy metal), aos quais sugerimos adicionar alguns tipos de hackers, punks e skinheads. Um aspecto não analisado por Arnett (2002) é que o fluxo de informações na globalização não é apenas unidirecional como transparece no seu artigo. Yoga, tai chi chuan e outras técnicas orientais de meditação, há vários anos, são hábitos de parte da população das sociedades urbanas industrializadas do Ocidente. No mundo acadêmico, a meditação e o conceito de self do budismo sairam dos domínios da religião e da filosofia e encontram-se presentes, de forma incipiente, na medicina psicossomática (Davidson et al, 2003; Speca et al., 2000), nas neurociências cognitivas (Varela, Thompson e Rosch, 2003) e na Psicologia (Seeman, Dubin \& Seeman, 2003; Dingfeldeer, 2003). Nas palavras do neurocientista Francisco Varela (2003, p. 47), a meditação "pode ser considerada um tipo de experimentação que faz descobertas sobre a natureza e o comportamento da mente".

Em suma, como resultado da globalização econômica e cultural, as pessoas mais jovens encontram-se, cada vez mais, frente a questões de escolhas entre identidades culturais diferentes e, às vezes, conflitantes com os valores sociais tradicionais.

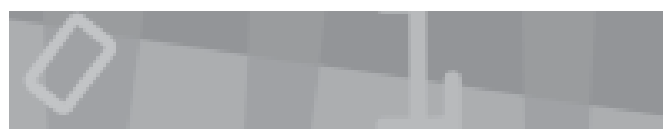

\section{Considerações Finais}

A internet é um meio de comunicação de massa interativa diferente das mídias convencionais, mas com alcance e penetração semelhante e potencialmente mais abrangente entre os jovens, envolvendo direta ou indiretamente atividades e organizações em todos os níveis da sociedade. Compreender o alcance da convergência dos meios digitais, dos problemas e possibilidades positivas para a sociedade é tarefa fundamental também para a Psicologia, em particular a sua influência nas relações de trabalho e nas formas emergentes de relacionamentos pessoais através dos meios digitais, que contribuem para a formação de novas identidades e para a desestruturação de identidades baseadas nas culturas locais.
Em resumo, a internet, como mídia, é um importante meio para atividades que ajudam a formar identidades $e$ subjetividades. 


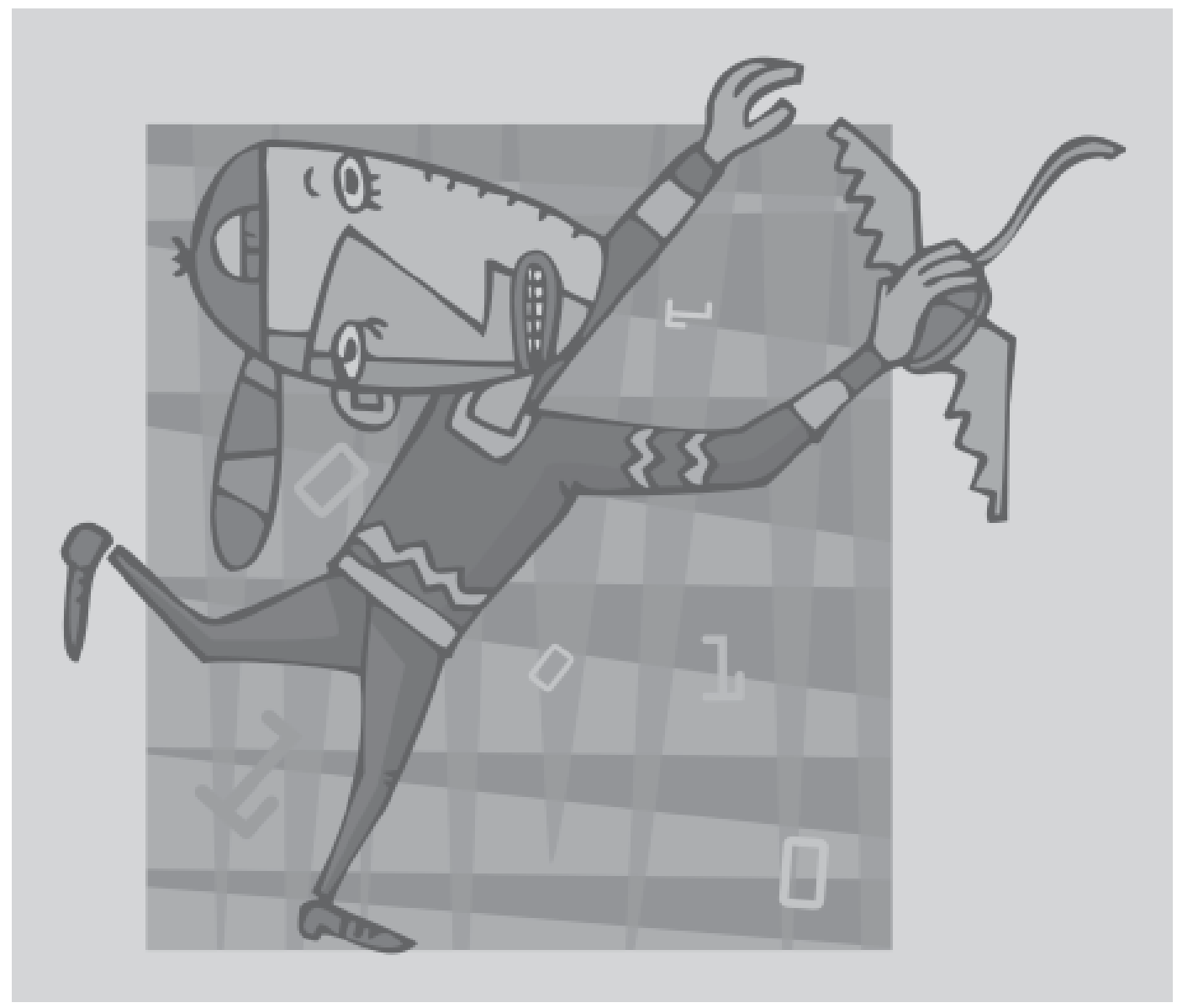


ABRAMO, P. Padrões de Manipulação na Grande Imprensa. São Paulo: Editora Fundação Perceu Abramo, 2003.

ARNETT, J. J. The Psychology of Globalization. American Psychologist, v. 58, n.1, Oct. 2002, pp. 774-783.

BARBER, B. R. Cultura McWorld. In Moraes, D. (org.) Por uma Outra Comunicação: Mídia, Mundialização Cultural e Poder. Rio de Janeiro: Record, 2000, pp. 41-56.

BEE, H. O Ciclo Vital. Porto Alegre, RS: ArtMed, 1997.

BELAR, C. D., NELSON, P. D. \& WASIK, B. H. Rethinking Education in Psychology and Psychology in Education. American Psychologist, v.58, n.8, Aug, 2003, pp.678-683.

BOSI, E. Comunicação de Massa: o Dado e o Problema. In Cultura de Massa e Cultura Popular, Leituras de Operárias. 5. ed. Petrópolis: Vozes, 1981, pp. 29-62.

CASTELLS, M. O Poder da Identidade. São Paulo: Paz e Terra, 2000.

CASTELLS, M. A Galáxia da Internet. Rio de Janeiro: Jorge Zahar, 2003a.

CASTELLS, M. Internet e Sociedade em Rede. In Moraes, D. (org.), Por uma Outra Comunicação: Mídia, Mundialização Cultural e Poder. Rio de Janeiro: Record, 2003b, pp. 255-288

CLAY, R. A. Linking up Online. Monitor on Psychology, v. 31, n. 4, Oct. 2000. Disponível em <http://www.apa.org/monitor >. Acesso em 21/12/2003.

DAVIDSON, R. J. et al. Alterations in Brain and Immune Function Produced by Mindful Meditation. Psychosomatic Medicine, n. 65, 2003, pp. 564-570.

DEANGELIS, T. Is Internet Addiction Real? Monitor on Psychology, v. 31, n. 4 Oct. 2000. Disponível em <http://www.apa.org/monitor>. Acesso em 21/12 2003.

DEFLEUR, M. L., BALL-ROKEACH, S. Teorias da Comunicação de Massa. Rio de Janeiro: Jorge Zahar, 1993.

DINGFELDER, S. F. Tibetan Budism and Research Psychology: a Match Made in Nirvana? Monitor on Psychology, v. 34, n. 11, Dec. 2003, pp. 46-48.

ECO, U. Apocalípticos e Integrados. São Paulo: Perspectiva, 1976.

EIDELWEIN, K. e MARASCHIN, C. O Operar de um Coletivo na WEB. Psicologia: Ciência e Profissão, v. 23, n.4, 2003, pp. 48-55.

FERREIRA, G. M. As Origens Recentes: os Meios de Comunicação Pelo Viés do Paradigma da Sociedade de Massa. In Hohlfeldt, A., Martino, L. C., França, V. V. (orgs.) Teorias da Comunicação: Conceitos, Escolas e Tendências. Petrópolis, RJ: Vozes, 2001, pp. 99-118.

FOXHALL, K. A Renaissance for Everyone? Monitor on Psychology, v. 31, n. 4, oct. 2000. Disponível em <http://www.apa.org/monitor>. Acesso em 21 $12 / 2003$.

GONÇALVES, M. S. O Amor no Ciberespaço. Ciência Hoje, v.28, n.163, pp.18$24,2000$.

KRAUT, R., OLSON, J., BANAJI, M., BUCKMAN, A., COHEN, J. \& COUPER, M. Psychological Research Online: Opportunities and Challenges. Disponível em <httr://www.apa.org/science/bsaweb-agcri.html> Acesso em 21/12/2003.

HOHLFELDT, A., MARTINO, L. C., FRANÇ, V. V. (orgs.) Teorias da Comunicação: Conceitos, Escolas e Tendências. Petrópolis, RJ: Vozes, 2001.

LEITÃO, C. \& NICOLACI-DA-COSTA, A. M. Psicologia Clínica e Informática: por que essa Inusitada Aproximação? Psicologia Clínica, v. 12, n. 2, 2000, pp. 189-205.
LEITÃO, C. \& NICOLACI-DA-COSTA, A. M. A Psicologia no Novo Contexto Mundial. Estudos de Psicologia (Natal), v.8, n.3, 2003, pp.421-430.

Referências

LEVY, P. A Máquina Universo: Criação, Cognição e Cultura Informática. Porto Alegre: Artmed, 1998

LEVY, P. Pela Ciberdemocracia. In Moraes, D.(org.) Por uma Outra Comunicação: Mídia, Mundialização Cultural e Poder. Rio de Janeiro: Record, 2003, pp. 367-384

MARTINO, L. C. Interdisciplinaridade e Objeto de Estudo da Comunicação. In Hohlfeldt, A., Martino, L. C., França, V. V. (orgs.). Teorias da Comunicação: Conceitos, Escolas e Tendências. Petrópolis, RJ: Vozes, 2001, pp. 27-38.

MORAES, D. (org.). Por uma Outra Comunicação: Mídia, Mundialização Cultural e Poder. Rio de Janeiro: Record, 2003.

MORIN, E. Os Sete Saberes Necessários à Educação do Futuro. São Paulo: Cortez; Brasília: Unesco, 2002

NICOLACI-DA-COSTA, A. M. Quem Disse que é Proibido Ter Prazer Online? Psicologia: Ciência e Profissão, v. 22, n.2, 2002a, pp. 12-21.

Internet: a Negatividade do Discurso da Mídia Versus a Positividade da Experiência Pessoal. À qual Dar Crédito? Estudos de Psicologia (Natal), v. 7, n. 1, 2002b, pp.25-35.

Revoluções Tecnológicas e Transformações Subjetivas. Psicologia: Teoria e Pesquisa, v.18 n.2, 2002c, pp.193-202.

Ciberespaço: Nova Realidade, Novos Perigos, Novas Formas de Defesa. Psicologia: Ciência e Profissão, v. 23, n.2, 2003, pp. 66-75. NOTO, A. R., FORMIGONI, M.L.O.S. A Política de Saúde Pública no Brasil. Ciência Hoje, v.31, n.181, 2002, pp. 45-47.

PIGNATARI, D. Informação, Linguagem, Comunicação. São Paulo: Cultrix, 1996

PINTO DEALMEIDA, L. e RODRIGUES, J. T. Narrativa e Internet: Possibilidades e Limites do Atendimento Psicoterápico Mediado Pelo Computador. Psicologia: Ciência e Profissão, v. 23, n.3, 2003, pp. 10-17.

RIBEIRO, D. O Povo Brasileiro: a Formação e o Sentido do Brasil. São Paulo: Companhia das Letras, 1995.

SEEMAN, T. E., DUBIN, L. F, SEEMAN, M. Religiosity/Spirituality and Health: a Critical Review of the Evidence for Biological Pathways. American Psychologist, v. 58, n. 1, Jan. 2003, pp. 53-63.

SILVERSTONE, R. Por que Estudar a Mídia? São Paulo: Loyola, 2002.

SOUZA, M. Televisão, Violência e Efeitos Midiáticos. Psicologia: Ciência e Profissão, v. 23, n.4, 2003, pp. 82-87.

SPECA, M., CARLSON, L. E., GOODEY, E., ANGEN, M. A Randomized, Waitlist Controlled Clinical Trial: the Effect of a Mindful Meditation-based Stress Reduction Program on Mood and Symptoms of Stress in Cancer Outpatients. Psychosomatic Medicine, n. 62, 2000, pp. 613-622.

VARELA, F. J., THOMPSON, E., ROSCH, E. AMente Incorporada: Ciências Cognitivas e Experiência Humana. Porto Alegre, RS: ArtMed, 2003.

TERÊNCIO M. G. \& SOARES, D. H. P. A Internet Como Ferramenta Para o Desenvolvimento da Identidade Profissional. Psicologia em Estudo, v. 8, n.2, 2003, pp.139-145.

ZALUAR, A. Drogas, um Panorama no Brasil e no Mundo. Ciência Hoje, v.31, n.181, p. 32-35, 2002 